\title{
Analysis of the feeding habits of the swallow-tailed hummingbird, Eupetomena macroura (Gmelin, 1788), in an urban park in southeastern Brazil
}

\author{
Toledo, MCB. * and Moreira, DM.* \\ Laboratório de Ecologia, Instituto Básico de Biociências, Campus Bom Conselho, \\ Universidade de Taubaté - UNITAU, \\ Av. Tiradentes, 500, CEP 12030-180, Taubaté, SP, Brazil \\ *e-mail: cecilia@unitau.br, demoreira81@yahoo.com.br \\ Received September 21, 2006 - Accepted July 13, 2007 - Distributed May 31, 2008
}

(With 2 figures)

\begin{abstract}
The aim of this work was to observe and describe the feeding habits and available food resources of the swallow-tailed hummingbird, Eupetomena macroura. The study was carried out in a municipal park located in the city of Taubaté, in the state of São Paulo. The observations took place between December 2003 and October 2004, recording the following variables: 1) the plant species visited for feeding and territorial defense; 2) the kinds of food resources; and 3) the kinds of flight to procure and obtain food. E. macroura visited 12 plant species. For territorial defense, Mangifera indica was the most visited, whereas Malvaviscus arboreus was most visited for feeding. The foliage was the plant part that received the most frequent visits. In order to obtain nectar, the only species visited was $M$. arboreus; to obtain arthropods, the species most visited were Mangifera indica and Hymenaea stilbocarpa. In the dry season, the hummingbirds visited flowers, whereas in the rainy season they visited leaves to acquire food. The arthropod groups most frequently found on leafy branches were Homoptera and Psocoptera. Finally, the results of the type of flight analysis showed that flight used to capture food was more often observed than were flights to search for food. In conclusion, these observations suggest that E. macroura shows plasticity in feeding behavior, which can help it to persist in urban areas.
\end{abstract}

Keywords: urban area, Eupetomena macroura, swallow-tailed hummingbird, feeding behaviour, arthropods, nectar.

\section{Análise do comportamento alimentar do beija-flor tesourão, Eupetomena macroura (Gmelin, 1788), em um parque urbano localizado na região sudeste do Brasil}

\begin{abstract}
Resumo
O objetivo deste trabalho foi observar e descrever o hábito alimentar do Beija-flor Tesourão, Eupetomena macroura. O estudo foi realizado em um parque municipal, situado na cidade de Taubaté, Estado de São Paulo. As observações ocorreram entre dezembro de 2003 e outubro de 2004, período em que foram observadas as seguintes variáveis: 1) as espécies de plantas visitadas para alimentação e defesa territorial; 2) o tipo de recurso alimentar; e 3) a frequiência de vôo para busca e obtenção de alimento. Foram registradas 12 espécies de plantas visitadas pelo E. macroura, visto que Mangifera indica e Malvaviscus arboreus foram as mais utilizadas para defesa territorial e para alimentação, respectivamente. O maior índice de flores visitadas foi observada para Malvaviscus arboreus. Mangifera indica e Hymenaea stilbocarpa foram as espécies que apresentaram maior freqüência de visita em folhas e ramos. Na estação seca, o beijaflor tesourão visitou flores para obtenção de alimento, já na estação úmida a maior parte do alimento foi adquirida entre folhas e ramos. Quando analisados as folhas e ramos visitados pelos indivíduos quanto à presença de artrópodes, os resultados obtidos indicaram que os grupos mais abundantes foram Homoptera e Psocoptera. Finalmente, pela análise do tipo de vôo, observou-se que o vôo que representa captura de alimento foi mais vezes observado do que aquele que é utilizado para procura de alimento. Os resultados sugerem uma flexibilidade trófica do E. macroura, fato que pode auxiliar na permanência da espécie em áreas urbanas.
\end{abstract}

Palavras-chave: área urbana, Eupetomena macroura, beija-flor tesourão, comportamento alimentar, artrópodes, néctar. 


\section{Introduction}

Among the members of the family Trochilidae, the swallow-tailed hummingbird Eupetomena macroura attracts a lot of attention because of its length of $18 \mathrm{~cm}$, its long bifurcated tail, and its aggressive territorial behavior (Morales, 2003; Pizo and Silva, 2001). In urban areas, hummingbirds occur widely in treed areas such as parks, plazas, boulevards, gardens and yards. Eupetomena macroura is one of the most abundant species in cities, being present in the greener urban areas where the presence of ornithophilous plant species is a basic requirement (Morales, 2003). Some urban green areas have little variety of plants that have nectar-producing flowers, and even fewer that flower year-round (Morais, 1999). Another aggravating factor for urban avifauna, cited by Argel-de-Oliveira (1996), is the partial or total replacement of native vegetation by exotic species during urbanization, making it difficult for birds to colonize and remain in these areas.

Members of the Trochilidae are mainly attracted by flowers that provide energy via their nectar (Varassin et al., 2001; Sick, 1997; Collins et al., 1990; Martínez del Río, 1990), which is considered the staple food of hummingbirds. This interaction between flowers and hummingbirds has spawned a large number of studies that seek to understand this co-evolved symbiotic behavior (Mendonça and Anjos, 2005; Varassin and Sazima, 2000). However, Yanega and Rubega (2004) claimed that the exaggerated focus given to this interaction between hummingbirds and nectar may have obscured other important evolutionary aspects of these species.

The symbiosis between the bird and a scarce resource such as nectar-producing flowers could presumably explain the specialized morphology and locomotion of hummingbirds. On the other hand, this structural and functional co-evolution demands one of the highest rates of energy consumption in the animal kingdom, which renders fragile the cost-benefit relationship that would allow the maintenance of stable populations of hummingbirds (Bicudo and Chaui-Berlink, 1998; Weale et al., 2000), especially in unfavorable environments. One hypothesis to explain the presence of these species in places with less available resources could be the fact that specialization could have opened a window of opportunity for hummingbirds to expand on their trophic niche by obtaining different types of food, e. g., arthropods.

According to Mendonça and Anjos (2005), few studies have been dedicated to understanding the biotic interactions of hummingbirds in urban systems. In this study, therefore, we posed the following questions: 1) Which plant species do swallow-tailed hummingbirds use for foraging and/or territorial defense? 2) With what relative frequency do swallow-tailed hummingbirds use hovering and flitting? 3) Are there variations in the dietary composition of swallow-tailed hummingbirds in a green urban area? and 4) Does the diet change from the dry season (more flowers available) to the rainy season?

\section{Materials and Methods}

\subsection{Study area}

The work was carried out in the municipality of Taubaté $\left(23^{\circ} 03^{\prime} 00^{\prime \prime} \mathrm{S}\right.$ and $45^{\circ} 35^{\prime} 46^{\prime \prime} \mathrm{W}$; $22^{\circ} 59^{\prime} 32^{\prime \prime} \mathrm{S}$ and $\left.45^{\circ} 31^{\prime} 5^{\prime \prime} \mathrm{W}\right)$, located in the Paraíba Valley, São Paulo State, Brazil. Taubaté is classified as a medium-size city $(244,000$ inhabitants $)$ that covers $626 \mathrm{~km}^{2}$ of which $66.88 \mathrm{~km}^{2}$ is urbanized (IBGE 2004). Most of the city is located on sedimentary soils in a region of flat land at an altitude of 500 to $575 \mathrm{~m}$. The climate of the region is classified as Cwa according to the Köppen scale, with rainy summers and dry winters. The hydrological year begins in August and ends in July of the following year, with $40 \%$ of the rainfall occurring between December and February, and the dry period occurring from May to August (Fisch, 1995).

The study was carried out in the Renato Corrêa Penna Municipal Nursery, which is a public area for recreation (Figure 1). Inside the park there is a small forest of early secondary growth, containing trees approximately five metres in height. In addition to this forested area, the park contains a lake, and fruit and ornamental trees are scattered throughout.

\subsection{Observations of foraging}

Observations were made in the entire study area, from December 2003 to October 2004, using Swift binoculars $(8.5 \times 0.44)$. Each three-hour period of daytime observation was considered a sample unit. The observations were made on various days of the month, in the morning (7:00-10:00 AM) and/or afternoon (3:00-6:00 PM), for at least 21 hours per month, totaling 222 hours. The technique used was the focal subject method, which consists of watching one individual for a known period of time. The focal individual (FI) was tracked for as long as it remained visible to the observer; only when the FI was lost from the field of view, was another specimen then identified and observed. The frequency of a particular behaviour was obtained from the ratio of the number of times that a behaviour was recorded to the total number of hours of observation (all sample units combined). Whenever possible, the same individual was not observed more than once during a sample unit. Those plants in which the hummingbird was observed defending territory or seeking or acquiring food, as well as plants used for resting, were considered as species visited. During the time when the FI was being observed, records were kept on:

1) Type of flight: two main types of flight were noted: a) hovering, a characteristic flight used by hummingbirds during the acquisition of food; and b) flitting, a flight that defines food-searching behavior (Sick, 1997);

2) Feeding: during each sample unit, records were made of which plant species were visited and how many times they were visited by the FI in search of nectar or arthropods. Records were also 


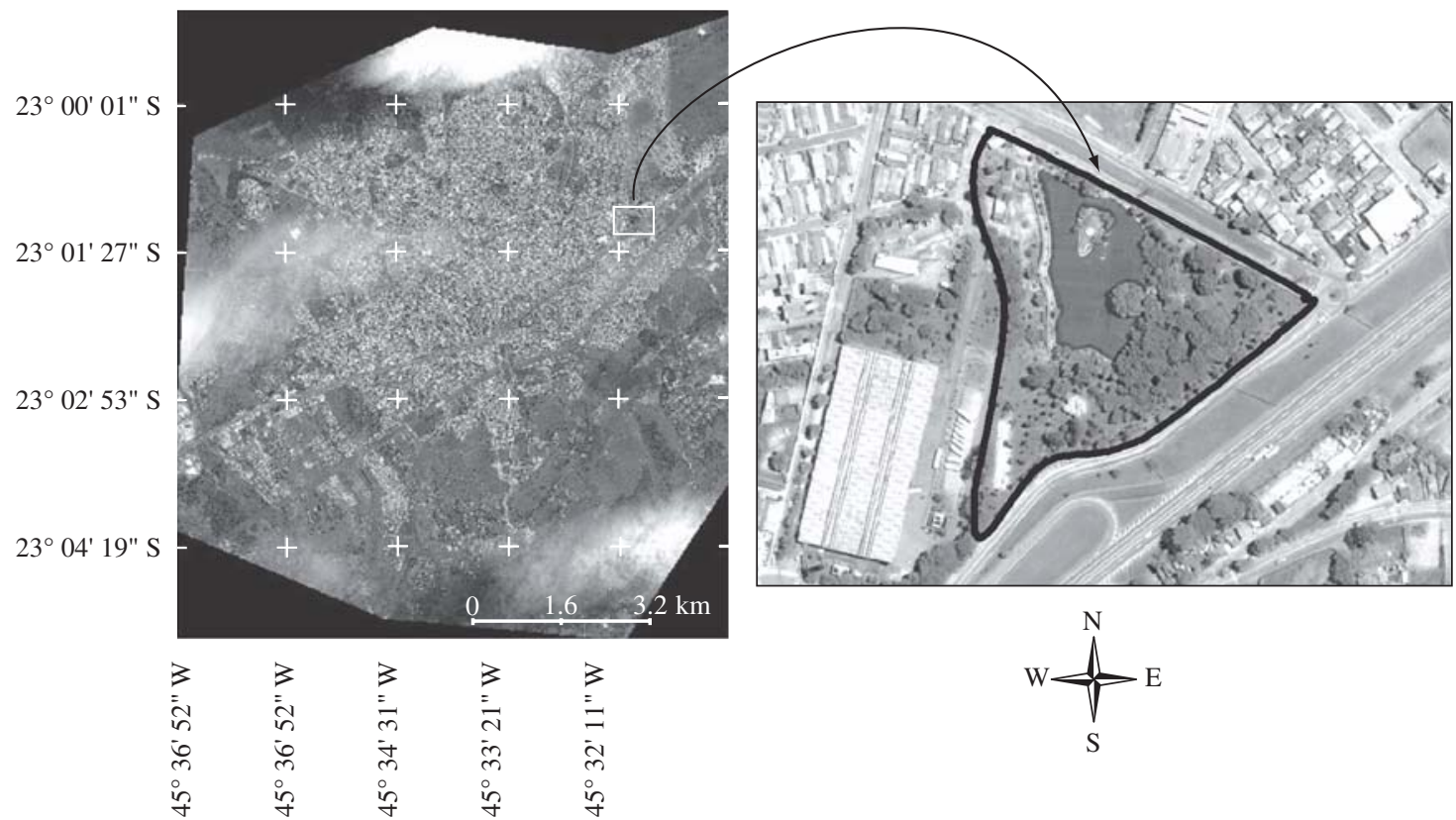

Figure 1. Satellite images (OrtoQuickColor 2006; $0.60 \mathrm{~m}$ of resolution; UTM, Datum WGS 84) of the urban area of Taubaté, São Paulo State, Brazil. The arrow indicates the study area, the Renato Corrêa Penna Municipal Nursery.

kept concerning which part of the plant was most visited: flower, foliage or branch; and

3) Territorial defense: This behavior was identified when the FI left the guarded area in order to attack other birds of the same or different species. Those plant species on which the FI remained perched, watching its territory, were identified, as well as the number of times this behaviour was observed.

The plant species were identified from plant parts (flowers, leaves, and fruits), which were taken to the Botanical Laboratory of the University of Taubaté, where the material was then identified and stored.

To collect the arthropods present on the plants visited by E. macroura, the branch-clipping method was used (Johnson, 2000; Hutto, 1990). To apply the method, the most frequently visited trees (over 10 visits) were selected. Two collections (March and September 2004) were made at the height where foraging had been observed, each of them with ten samples of each plant. After the branches were collected and placed in sacks, they were sprayed with insecticide (pyrethrin and pyrethroid) and taken to the laboratory, where the arthropods were separated and preserved in 70\% alcohol. Before all arthropods present on the branches were collected, the sack was lightly shaken so as to dislodge them. Only then was the sack opened and the branch removed for examination; next, the sack itself was examined. The leaves were removed from the branch and scrutinized by hand with a magnifying lens and tweezers. A total of 686 leaves were examined. The arthropods collected were taken to the Entomology Laboratory of the Agronomy Department at the University of Taubaté, where they were identified according to the morpho-species to which they belong, according to Borror and Delong (1969).

To analyze the data, Shapiro-Wilk Normality tests were performed. According to the results obtained, first the Friedman Test (FR) was used and then the Dunn Test (D), both non-parametrically, for a multiple comparison of averages. For a comparison of proportions, a Chi-square test was used, at a significance level of 95\% (Zar, 1997).

\section{Results}

During the entire period of observation, individuals of $E$. macroura visited a total of 12 plant species for territorial defense or feeding. The number of entries recorded for defense of territory (506) was higher than for foraging (414) (Table 1). For territory defense, $M$. indica was the most frequently visited (37\%); M. arboreus received the highest number of visits for hovering and flitting $(67.8 \%)$.

There were significant differences between the frequencies of visits to plant species used for defense of territory $(\mathrm{FR}=28.85 ; \mathrm{DF}=6 ; \mathrm{p}<0.0001)$ and for foraging $(\mathrm{FR}=33.07 ; \mathrm{DF}=4 ; \mathrm{p}<0.0001)($ Table 2$)$.

Regarding the type of flight, hovering was more frequent $(70 \%)$ than flitting $(30 \%)$ (Table 1). There was a significant difference between the number of visits made by E. macroura to distinct plants for hovering but not for flitting (Table 3). 
Table 1. Plant species visited by E. macroura, their relative abundance (RA) in the study area, and number of visits at each plant for foraging and territorial defense.

\begin{tabular}{lrrrr}
\hline \multicolumn{1}{c}{ Plant species } & RA $(\%)$ & \multicolumn{2}{c}{ Foraging } & Territorial defense \\
\cline { 3 - 4 } & & Hovering & Flitting & \\
\hline Inga sp. & 2.1 & 0 & 17 & 1 \\
Hymenaea stilbocarpa & 2.1 & 11 & 2 & 2 \\
Hibiscus rosa-sinensis & 14.6 & 4 & 69 & 77 \\
Malvaviscus arboreus & 20.8 & 214 & 0 & 15 \\
Psidium guayava & 4.2 & 1 & 33 & 184 \\
Mangifera indica & 22.9 & 47 & 0 & 1 \\
Codiaeum variegatum & 2.1 & 1 & 2 & 124 \\
Mimosa bimucronata & 12.5 & 6 & 0 & 53 \\
Triplaris brasiliana & 8.3 & 1 & 0 & 1 \\
Tabebuia sp. & 4.2 & 1 & 1 & 3 \\
Bougainvilhea glabra & 4.2 & 2 & 0 & 5 \\
Cecropia sp. & 6.3 & 1 & 125 & 506 \\
Totals & - & 289 & & \\
\hline
\end{tabular}

Table 2. Friedman pre-test (FR) and Dunn post-test (D) used to verify differences in the behaviour of $E$. macroura for feeding and for territorial defense. Those plants whose relative abundances were less than $10 \%$ in the study area (see Table 1), that is, 1 or 2 specimens available for visits were excluded from this analysis.

\begin{tabular}{|c|c|c|c|c|c|}
\hline \multicolumn{6}{|c|}{ Feeding $(\mathrm{FR}=33.07 ; \mathrm{DF}=4 ; \mathrm{p}<0,0001)$} \\
\hline & H. stilbocarpa & M. arboreus & M. indica & - & - \\
\hline Hymenaea stilbocarpa & - & $\mathrm{D}=63.5 ; \mathrm{p}<0.05$ & $\mathrm{D}=30.5 ; \mathrm{p}>0.05$ & - & - \\
\hline Malvaviscus arboreus & - & - & $\mathrm{D}=33 ; \mathrm{p}>0.05$ & - & - \\
\hline \multicolumn{6}{|c|}{ Territoral defense $(\mathrm{FR}=28.85 ; \mathrm{DF}=6 ; \mathrm{p}<0,0001)$} \\
\hline & H. stilbocarpa & M. arboreus & P. guayava & M. indica & M. bimucronata \\
\hline Hymenaea stilbocarpa & - & $\mathrm{D}=37 ; \mathrm{p}>0.05$ & $\mathrm{D}=37 ; \mathrm{p}>0.05$ & $\mathrm{D}=42 ; \mathrm{p}>0.05$ & $\mathrm{D}=3 ; \mathrm{p}>0.05$ \\
\hline Malvaviscus arboreus & - & - & $\mathrm{D}=61 ; \mathrm{p}<0.05$ & $\mathrm{D}=5 ; \mathrm{p}>0.05$ & $\mathrm{D}=34 ; \mathrm{p}>0.05$ \\
\hline Psidium guayava & - & - & - & $\mathrm{D}=66 ; \mathrm{p}<0.05$ & $\mathrm{D}=27 ; \mathrm{p}>0.05$ \\
\hline Mangifera indica & - & - & - & - & $\mathrm{D}=39 ; \mathrm{p}>0.05$ \\
\hline
\end{tabular}

Table 3. Friedman pre-test (FR) and Dunn post-test used to verify differences in the behaviour of E. macroura for foraging (hovering as opposed to flitting). Those plants whose relative abundances were less than $10 \%$ in the study area (see Table 1), that is, 1 or 2 specimens available for visits were excluded from this analysis.

\begin{tabular}{|c|c|c|c|c|c|}
\hline \multicolumn{6}{|c|}{ Hovering $(\mathrm{FR}=22,78 ; \mathrm{DF}=4 ; \mathrm{p}<0,0001)$} \\
\hline & H. stilbocarpa & H. rosasinensis & M. arboreus & M. indica & M. bimucronata \\
\hline Hymenaea stilbocarpa & - & $\mathrm{D}=4 ; \mathrm{p}>0.05$ & $\mathrm{D}=55 ; \mathrm{p}<0.05$ & $\mathrm{D}=14 ; \mathrm{p}>0.05$ & $\mathrm{D}=0 ; \mathrm{p}>0.05$ \\
\hline Hibiscus rosasinensis & - & - & $\mathrm{D}=59 ; \mathrm{p}<0.05$ & $\mathrm{D}=18 ;>0.05$ & $\mathrm{D}=4 ; \mathrm{p}>0.05$ \\
\hline Malvaviscus arboreus & - & - & - & $\mathrm{D}=41 ;<0.05$ & $\mathrm{D}=55 ; \mathrm{p}<0.05$ \\
\hline Mangifera indica & - & - & - & - & $\mathrm{D}=14 ; \mathrm{p}>0.05$ \\
\hline \multicolumn{6}{|c|}{ Flitting $(F R=3.976 ; D F=2 ; p=0,1369)$} \\
\hline & H. stilbocarpa & M. arboreus & M. indica & - & - \\
\hline Hymenaea stilbocarpa & - & $\mathrm{D}=-11.50 ; \mathrm{p}>0.05$ & $\mathrm{D}=-11 ; \mathrm{p}>0.05$ & - & - \\
\hline Malvaviscus arboreus & - & - & $\mathrm{D}=0.5 ; \mathrm{p}>0.05$ & - & - \\
\hline
\end{tabular}


The results show that E. macroura spends more of its time in feeding than in seeking food, according to the Mantel-Haenszel Chi-square test $\left(\chi^{2}=37.71 ; p=0.052\right)$. These differences between seeking and obtaining food varied among plant species used by $E$. macroura $\left(\chi^{2}=26.17 ; \mathrm{DF}=11 ; \mathrm{p}=0.0061\right)$. In the case of M. arboreus, the most sought-after plant species, a significant difference was recorded $\left(\chi^{2}=74.29 ; \mathrm{p}=0.000\right)$ between the number of visits made for searching $(75.6 \%$; $\mathrm{n}=214)$ and for acquiring $(24.4 \% ; \mathrm{n}=69)$ food, when the premise of equal proportions was expected. However, in the visits made to $M$. indica, the portions ascribed to search $(58.7 \% ; \mathrm{n}=47)$ and acquisition $(41.3 \% ; \mathrm{n}=33)$ of food were similar $\left(\chi^{2}=2.45 ; \mathrm{p}=0.1175\right)$, as expected. The part of the plant most visited, regardless of species and type of visit, was the foliage $(57.9 \%$; $\mathrm{n}=919)$, followed by the flowers $(42.1 \% ; \mathrm{n}=667)$. This difference in proportions was significant $\left(\chi^{2}=39.73 ; \mathrm{p}=0.0000\right)$. Even considering only the visits to the foliage, the plant species most visited by $E$. macroura was $M$. indica, followed by H. stilbocarpa.

From the collection of branches of $M$. indica ( $\mathrm{n}=317$ leaves) and H. stilbocarpa $(\mathrm{n}=369$ leaves $)$, the following orders of arthropods were found: Homoptera ( $\mathrm{n}=108)$; Psocoptera $(\mathrm{n}=55)$; Hemiptera $(\mathrm{n}=34)$; Araneae $(\mathrm{n}=29)$; Coleoptera $(\mathrm{n}=8)$; Hymenoptera $(\mathrm{n}=7)$; Diptera $(\mathrm{n}=6)$; Orthoptera $(\mathrm{n}=1)$; and. Acari $(\mathrm{n}=1)$. Unidentified insects $(\mathrm{n}=15)$, insect parts $(\mathrm{n}=2)$, and exuviae $(n=636)$ were found as well. Thus, the most commonly found arthropods were the Homoptera $(40.9 \%)$ and the Psocoptera (20.8\%). Also recorded was a large number of spider webs without spiders $(n=215)$ and a few live spiders and oothecae $(\mathrm{n}=18)$.

The swallow-tailed hummingbirds most often visited the foliage during the rainy season, from September to March, and most often the flowers during the dry months, from April to August (Figure 2). This difference between the dry and rainy periods was significant $\left(\chi^{2}=511 ; p=0.0000\right)$. In the rainy season, the birds vis-

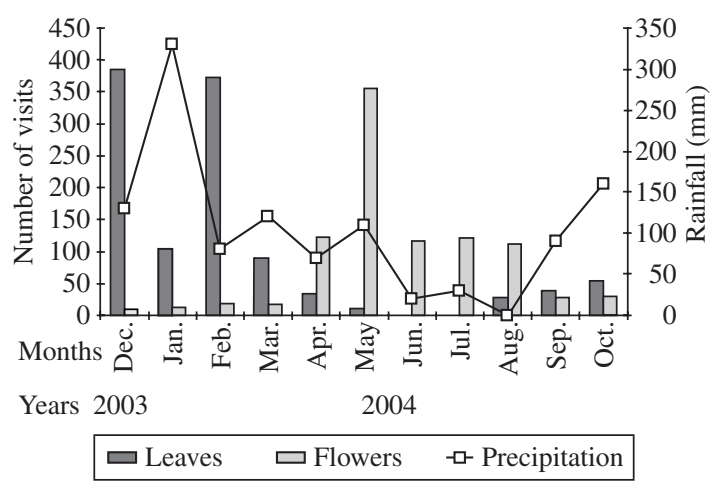

Figure 2. Monthly variation in the number of E. macroura visits to flowers and leaves (left axis) and rainfall data from the Meteorological Station of the University of Taubaté (right axis) from December 2003 to October 2004. ited flowers only $11.4 \%$ of the time ( $\mathrm{n}=74)$, but in the dry season $88.2 \%(n=593)$ of the visits were to flowers. The reverse was true for visits to leaves: in the dry season $1.2 \%(\mathrm{n}=11)$ and in the rainy season $98.4 \%(\mathrm{n}=905)$ of the visits were to leaves.

\section{Discussion}

\subsection{Use of available resources}

The greater or lesser availability of plant species utilized for territory defense does not appear to be associated with any preference for a certain plant resource. Normally the plant species that E. macroura chose for resting were composed of few leaves, a strategic location that could permit greater spatial visibility. In the analysis of the behaviour of another hummingbird, Amazilia rutila, as to the vegetation utilized for its territorial defense, Schemske (1974) also concluded that the choice of vegetation is a function of its strategic location.

According to Collins et al. (1970), Young (1971), and Wolf and Stiles (1970), the factors that may attract hummingbirds to a particular territory are the flowering patterns, nectar preferences, and the spatial and temporal distribution of food sources.

Besides Malvaviscus arboreus, other nectar-producing plants, such as Tabebuia, Hibiscus, Bougainvillea, and Ing $a$, often cited as attractive to hummingbirds elsewhere (Snow and Snow, 1986; Piratelli, 1993; Mendonça and Anjos, 2005; 2006), flowered in the study area during the driest period of the year. Nevertheless, it seems that the availability of flowering species does not mean that they will necessarily be used as food sources by Eupetomena macroura, given that we did not observe any visit of this hummingbird to flowers other than $M$. arboreus. As observed by Mendonça and Anjos (2005), this hummingbird visited only three of the 22 species of ornithophilous trees present at the urbanized area studied by them In a fragment of secondary forest, Piratelli (1993) observed the visits of hummingbirds to two species, Inga sp. and Jacaratia spinos, which flowered simultaneously in October, and found that E. macroura visited Inga sp. almost exclusively. This pattern was also noted in the present study: E. macroura visited $M$. arboreus much more often than any other species present in the area. E. macroura did not visit only nectar-producing species; there was also evidence of a closer interaction with plant species where it captured and fed upon arthropods. Young (1971), working in forested areas, observed that Phaetornis supercilliosus preferred to feed in Geonoma binervia rather than in Welfia georgii, even though both palms sheltered the same species of prey. For the swallow-tailed hummingbird, there are two alternative hypotheses to explain its selectivity:

1) Inter-species competition: in urban areas there are many different species of hummingbirds. Hofling and Camargo (2002) and Matarazzo-Neuberger (1995) recorded eight species of hummingbirds in the city of São Paulo; Mendonça and Anjos (2005) 
recorded ten species in the city of Londrina, besides other bird species such as Coereba flaveola, as well as butterflies, moths, ants, and bees that compete for flower nectar within a delimited area. According to Mendonça and Anjos (2005), intense competition for resources could lead to niche segregation, and Pyke (1980) added that such competition could create a specialization within a certain species, as in the case of Ramphodon naevius cited by Sazima et al. (1995); and

2) Characteristics of the plants: variations in the morphology of the flower and in the chemical composition of the nectar, as well as distinct availability of flowers during different seasons of the year, could allow for the segregation of resources (Mendonça and Anjos, 2003; López-Calleja, 2003). In the case of E. macroura, the search for a certain species in particular may be a function not only of the low diversity of ornithophilous species, but also of a low degree of segregation between blooming periods.

Malvaviscus arboreus offers a large nectar reward during a single day (Webb, 1984). In addition, this species has flowering peaks (April-August) but the population is in flower all year around (Mendonça and Anjos 2005, Opler et al. 1980). An extended flowering period may play an important role in maintaining pollinator fidelity and is very important to maintain the local population of E. macroura.

\subsection{Type of food resource}

That the greater number of visits recorded were for seeking out and not for the acquisition of nectar in $M$. arboreus could also be explained by competition. During field observations, the flowers of this species were often seen with holes made by $C$. flaveola, and we also observed ants and other small insects visiting the flowers. Competition such as this may force the individual to spend most of its time in search for food. This difference between the number of visits to $M$. indica in search of nectar was not observed during the acquisition of arthropods. Indeed, Young (1971) observed that Phaetornis superciliosus visited spider webs in open areas only a few times per day, resulting in less foraging time owing to the greater efficiency in acquiring arthropods. Feinsing and Colwell (1978) recorded arthropods that were captured accidentally by hummingbirds. In contrast, Montgomerie and Redsell (1980), observing two nests with adult couples of Selasphorus platycercus, confirmed that the adults spent most of their time acquiring arthropods during flight, on leaves, lichens, trunks, and tree branches. Similar observations were made by Zanotto and Bicudo (2005), who hypothesized that the reduction of time in the acquisition of proteins is associated with a different metabolic rate compared with that observed for sugars. Young (1971) included Phaethornis superciliosus in the guild of leaf-gleaning and webgleaning predators, which acquire dead arthropods from leaves and from spider webs. Other authors have re- corded some species that capture Drosophila sp. in flight (Yanega and Rubega, 2004) or that prefer spiders (Stiles, 1995; Young, 1971).

In fact, hummingbirds differ concerning their feeding dependence on arthropods. Studies to estimate the percentage of protein in hummingbird diets have yielded diverse results, ranging from $2 \%$ to $15 \%$ of the daily feeding time (Pyke, 1980); others spend up to $70 \%$ of their total foraging time capturing coleopterous insects (Wolf, 1970); and for still other species, this portion reaches $100 \%$, that is, exclusively insectivorous (Stiles, 1995). This variation of the dependence on arthropods can be a function of their scattered distribution in contrast with nectar sources that are punctual in the time and space.

Our field observations (data not shown) indicated that E. macroura territorial behavior is more evident while obtaining nectar from $M$. arboreus than when insects are the objective of food acquisition; that is, the birds spent more time hovering when in search of nectar. Some interacting factors that may play a role in this case may be competition, availability, and distribution of resources, and even the nutritive value of the nectar as opposed to protein value. Even though proteins are rich in amino acids $(\mathrm{N})$, a necessary element for many biological functions that are not totally supplied by nectar alone, nectar is rich in sucrose and is a better source of energy than proteinaceous sources. Malvaviscus arboreus can produce from $20 \mu \mathrm{L}$ (George, 1980) to $72 \mu \mathrm{L}$ (Webb, 1984) of nectar per flower, that has around $20 \%$ of sugar, which is equivalent to 100 calories per flower Arizmend, (2001). Another important factor is that nectar passes more rapidly through the digestive tract (Roxburgh and Pinshow, 2002) with a higher rate of assimilation (Zanotto and Bicudo, 2005). This explains the greater number of visits in search of nectar, which compensates for the cost of obtaining it.

Body size is another important factor in foraging because the larger species such as E. macroura $(18 \mathrm{~cm}$ in length) have a greater need for amino acids, which would impose feeding restrictions concerning an increase in protein intake (Schondube and Martínez del Río, 2004; McWhorter et al., 2003; Fernández et al., 2002).

As for the consumption of arthropods, the high proportion of Homoptera and Psocoptera present on the leaves sampled for our study does not mean that E. macroura is feeding on these arthropods. According to Cooper and Whitmore (1990), the mere occurrence of some types of arthropods does not reflect the availability of prey, because not all arthropods present in a foraging range may be consumed by birds. In this regard, we noted the high number of spider webs and oothecae without the presence of the individuals, leading to the hypothesis that E. macroura is feeding on these small spiders. This hypothesis is reinforced by the results of Stiles (1995), who analyzed the stomach contents of several hummingbirds and reported a pronounced preference for spiders in their diet and that the size of the spider had a perfect correlation with the size of the hum- 
mingbirds. In a study by Young (1971), the morphospecies commonly found in the undergrowth of tropical forests were Diptera, Hymenoptera, Homoptera, and Coleoptera, which were also observed in the vegetation of our study area, Homoptera being the most abundant and may be the most important resource during the period without flowers.

\subsection{Seasonality and the type of food source}

The results as to the greater or lesser consumption of arthropods or of nectar between the dry and rainy seasons agree with those of other researchers (Bouchard et al., 2000; Sick, 1997; Stiles, 1995; Collins et al., 1990). This variation may also be a function of the reproductive period of the bird, a period during which obtaining the most useful energy is important. Nevertheless, to assess to what degree the human-impacted environment influences the changes in the foraging behavior of E. macroura, it would be necessary to compare these results with those from non-impacted areas and areas where nectar production takes place year-round. The relationship between seasonality and type of food consumed coincided with the blooming periods of most of the species present in the study area.

However, the results obtained by Mendonça and Anjos (2005) in an area with a greater diversity of plant species, which flowered in different periods, showed that the swallow-tailed hummingbird did not vary its diet much, and yet had a low rate of visitation to flowers compared with other species of Trochilinae. Young (1971) also recorded variations during the year in the type of diet of Phaethornis superciliosus, a seasonality in which insect consumption increased during the rainy period over the dry period; however, the author did not compare the availability of nectar in his study area. In any case, as long as urbanized areas include green parks, one can expect to find hummingbird populations, even in the absence of nectar- producing flowers due to the dietary plasticity of some species. This is certainly true for E. macroura.

Acknowledgements - We gratefully acknowledge the suggestions given by Caio Graco Machado, Luciana Baza Mendonça, Maria Célia Villac, Reginaldo José Donatelli and José Ragusa Netto that greatly improved the original manuscript. This study was supported by Ford Taubaté and Alston Brasil.

\section{References}

ARGEL-DE-OLIVEIRA, MM., 1996. Aves Urbanas. Anais do V Congresso Brasileiro de Ornitologia, p. 151-156. Campinas, SP, UNICAMP, p. 151-156.

ARIZMENDI, MC., 2001. Multiple ecological interactions: nectar robbers and hummingbirds in a highland forest in Mexico, Can. J. Zool., vol.79, no. 6, p. 997-1006.

BICUDO, JEPW. and CHAUI-BERLINK, JG., 1998. Locomotion and thermogenesis in hummingbirds. Comparative Biochemistry and Physiology, vol. 120, no. 1, p. 27-33.
BORROR, DJ. and DELONG, DM., 1969. Introdução ao estudo dos insetos. São Paulo: Editora Edgard Blucher.

BOUCHARD, S., VONHOF, MJ., FENTON, MB. and MONETTE, G., 2000. Nutrient preferences of Brazilian hummingbirds. The Wilson Bulletin, vol. 112, no. 4, p. $558-562$.

COLLINS, BG., GREY, J. and MCNEE, S., 1990. Foraging and nectar use in nectarivorous bird communities. Studies in Avian Biology, no. 13, p. 110-121.

COOPER, RJ. and WHITMORE, RC., 1990. Arthropod sampling methods in ornithology. Studies in Avian Biology, no. 13 , p. 29-37.

FEINSINGER, P., and COLWELL, RK., 1978. Community organization among Neotropical nectar-feeding birds. American Zoologist, vol. 18, p. 779-795.

FERNANDEZ, MJ., LÓPEZ-CALEJA, MV. and BOZINOVIC, F., 2002. Interplay between the energetics of foraging and thermoregulatory costs in the green-backed firecrown hummingbird Sephanoides sephaniodes. Journal of Zoology, vol. 258, n. 3, p. 319-326

FISCH, G., 1995. Caracterização climática e balanço hídrico de Taubaté (SP). Revista Biociências - UNITAU, vol. 1, no. 1, p. 81-90.

GEORGE, MW., 1980. Hummingbird foraging behavior at Malvaviscus arboreus var. Drummondii. The Auk, vol. 97, no. 4, p. 790-794.

HÖFLING, E. and CAMARGO, EF., 2002. Aves no campus da Cidade Universitária Armando Salles Oliveira. $3^{\mathrm{a}}$ ed. Ed. USP. $157 \mathrm{p}$.

HUTTO, RL., 1990. Measuring the availability of food resources. Studies in Avian Biology, no. 13, p. 20-28.

IBGE, 2004. Instituto Brasileiro de Geografia e Estatística. [14/09/2006]. Available from: http://www.ibge.gov.br.

JOHNSON, MD., 2000. Evaluation of an arthropod sampling technique for measuring availability for forest insectivorous birds. Journal of Field Ornithology, vol. 7, no. 1, p. 88-109.

LÓPEZ-CALLEJA, MV., FERNÁNDEZ, MJ. and BOZINOVIC, F., 2003. The integration of energy and nitrogen balance in the hummingbird Sephanoides sephanoides. The Journal of Experimental Biology, vol. 206, no. 19, p. 3349-3359.

MATARAZZO-NEUBERGER, WM., 1995. Comunidade de aves de cinco parques e praças da Grande São Paulo, Estado de São Paulo. Ararajuba, vol. 3, p. 13-19.

MARTÍNEZ-DEL-RÍO, C., 1990. Sugar preferences in hummingbirds: the influence of subtle chemical differences on food choice. Condor., vol. 92, no. 4, p. 1022-1030.

McWHORTER, TJ., POWERS, DR. and MARTÍNEZ DEL RIO, C. 2003. Are Hummingbirds Facultatively Ammonotelic? Nitrogen Excretion and Requirements as a Function of Body Size. Physiological and Biochemical Zoology, vol. 76, n. 5, p. 731-743.

MENDONÇA, LB. and ANJOS, L., 2003. Bird-flower interactions in Brazil: a review. Ararajuba, vol. 11, no. 2, p. 43-53.

MENDONÇA, LB. and ANJOS, L., 2005. Beija-flores (Aves, Trochilidae) e seus recursos florais em uma área urbana do 
Sul do Brasil. Revista Brasileira de Zoologia, vol. 22, no. 1, p. 51-59.

MENDONCA, LB. and ANJOS, L., 2006 . Feeding behavior of hummingbirds and perching birds on Erythrina speciosa Andrews (Fabaceae) flowers in an urban area, Londrina, Paraná, Brazil. Revista Brasileira de Zoologia, vol. 23, n. 1, p. 42-49.

MONTGOMERIE, RD. and REDSELL, CA., 1980. A nesting hummingbird feeding solely on arthropods. Condor, vol. 82, no. 4 , p. $463-464$

MORAIS, ES., 1999. Comportamento alimentar de Coereba flaveola (Coerebidae) em Malvaviscus arboreus (Malvaceae) na cidade de São Paulo - SP. Bioikos., vol. 13, no. 1/2, p. 52-55.

MORALES, WT., 2003. Beija-flor-de-tesoura (Eupetomena macroura, Gmelin, 1788). [10/10/2006]. Available from: http:// www.vivabrasil.com/beija_flor_de_tesoura.htm.

OPLER, PA. 1980. Nectar production in a tropical ecosystem. In: Bentley B., Elias T., (Eds). The biology of nectaries. New York: Columbia University Press. p. 30-79.

PIRATELLI AJ., 1993. Comportamento alimentar de beijaflores em flores de Inga spp. (Leguminosae, Mimosoideae) e Jacaratia spinosa (Caricaceae) em um fragmento florestal do sudeste brasileiro. IPEF, no. 46, p. 43-51.

PIZO, MA. and SILVA, WR., 2001. The dawn lek of the swallow-tailed hummingbird. The Wilson Bulletin, vol. 113, no. 4, p. 388-397.

PYKE, GH., 1980. Why hummingbirds hover and honeyeaters perch. Animal Behavior, vol. 29, no. 3, p. 861-867.

ROXBURGH, L. and PINSHOW, B., 2002. Digestion of nectar and insects by Palestine sunbirds. Physiological and Biochemical Zoology, vol. 75, no. 6, p. 583-589.

SAZIMA, M., BUZATO, S. and SAZIMA, I., 1995. Polinização de Vriesea por morcegos no Sudeste brasileiro. Bromélia, no. 2, p. 29-37.

SCHEMSKE, DW., 1974. Time budget and foraging site preference of the cinnamon hummingbird in Costa Rica. Condor, vol. 77, no. 2, p. 216-217.

SCHONDUBE, JE. and MARTÍNEZ-DEL-RÍO, C., 2004 Sugar and protein digestion in flowerpiercers and hummingbirds: a comparative test of adaptive convergence. Journal of Comparative Physiology, vol. b 174, no. 3, p. 263-273.

SICK, H., 1997. Ornitologia Brasileira. Rio de Janeiro: Editora Nova Fronteira. 912 p.
SNOW, DW. and SNOW, BK., 1986. Feeding ecology of hummingbirds in the Serra do Mar, Southeastern Brazil. El Homero, vol. 12, p. 286-296.

STILES, FG., 1995. Behavioral, ecological and morphological correlates of foraging for arthropods by the hummingbirds of a tropical wet forest. Condor, vol. 97, no. 4, p. 853-878.

STILES, FG. and WOLF, LL., 1970. Hummingbird territoriality at a tropical flowering tree. The Auk, vol. 87, no. 3, p. 467-491.

VARASSIN, IG. and SAZIMA, M., 2000. Recursos de Bromeliaceae utilizados por beija-flores e borboletas em Mata Atlântica no Sudeste do Brasil. Bol. Mus. Biol. Mello Leitão, n. sér. 11/12, p. 57-70.

VARASSIN, IG., TRIGO, JR. and SAZIMA, M., 2001. The role of nectar production, flower pigments and odour in the pollination of four species of Passiflora (Passifloraceae) in south-eastern Brazi. Botanical Journal of the Linnean Society. vol. 136 , n. 2, p. 139-152.

WEALE, ME., WHITWELL D., RAISON, HE., RAYMOND, DL. and ALLEN, JA., 2000. The influence of density on frequency-dependent food selection: a comparison of four experiments with wild birds. Oecologia, vol. 124, no. 3, p. 391-395.

WEBB, CJ., 1984. Hummingbird pollination of Malvaviscus arboreus in Costa Rica. New Zealand journal of Botany, vol. 22, p. $575-581$.

WOLF, LL., 1970. Impact of seasonal flowering on hummingbirds. Condor, vol. 72, no. 1, p. 1-14

WOLF, LL. and STILES, FG., 1970. Evolution of pair cooperation in a tropical hummingbird. Evolution, vol. 24, n. 4, p. 759-773.

YANEGA, GM. and RUBEGA, MA., 2004. Hummingbird jaw bends to aid insect capture. This tiny bird has a neat trick to trap flies in mid-air with its long nectar-seeking beak. Nature, vol. 428, no. 6983, p. 615.

YOUNG, AM., 1971. Foraging for insects by a tropical hummingbird. The Condor, vol. 73, no. 1, p. 36-45.

ZANOTTO, FP. and BICUDO, JEPW., 2005. Las proteínas y carbohidratos dietarios afectan la conducta de alimentación y la regulación metabólica en picaflores (Melanotrochilus fuscus). Revista Chilena de História Natural, vol. 78, no. 2, p. 281-294.

ZAR, JH., 1997. Biostatistical Analysis. 3rd ed. New Jersey: Prentice Hall Inc. 929 p. 